\title{
Implementasi Metode Client Server pada Penerapan Aplikasi Simulasi Ujian Akhir
}

\author{
Alfiansyah Hasibuan ${ }^{1}$, Erwin Dalimunthe ${ }^{2}$ \\ ${ }^{1}$ Program Studi Sistem Komputer, Fakultas Sains dan Teknologi, Universitas Pembangunan Panca Budi, \\ Jl. Gatot Subroto No.km, Simpang Tj., Kec. Medan Sunggal, Medan, Indonesia, 20122 \\ e-mail: ${ }^{1}$ alfiansyah_hasibuan@ymail.com
}

Submitted Date: June $16^{\text {th }}, 2020$

Revised Date: June $26^{\text {th }}, 2020$
Reviewed Date: June $26^{\text {th }}, 2020$

Accepted Date: June $30^{\text {th }}, 2020$

\begin{abstract}
In the current era, where technology has become a necessity, not only in terms of information sources but also as a tool to process data. Client Server is a connectivity on the network that distinguishes computer functions whether as a client or server. This architecture makes a computer as a server or center in charge of providing services to other terminals (clients) connected to this network system. In this system, the design of the exam simulation by applying the client server method, where the computer used by students to answer questions is the client and the computer used by the lecturer to monitor and fill questions is a server. In solving problems that arise, an agency must have a system that can overcome these problems. The proposed system in overcoming problems is a computerized system to produce effective and efficient information, and to make reports more quickly and accurately. The exam simulation application designed is very helpful for lecturers to carry out and check exam results quickly and accurately.
\end{abstract}

Keywords: Client Server; architecture; lecturers; students.

\begin{abstract}
Abstrak
Pada era saat ini, di mana teknologi telah menjadi suatu kebutuhan, tidak hanya dalam hal sumber informasi melainkan juga sebagai alat untuk mengolah data. Client Server merupakan konektifitas pada jaringan yang membedakan fungsi komputer apakah sebagai client atau server. Arsitektur ini menjadikan sebuah komputer sebagai server atau pusat yang bertugas memberikan layanan-layanan kepada terminalterminal lain (client) yang terhubung pada sistem jaringan ini. Didalam sistem ini, rancangan simulasi ujian dengan menerapkan metode client server, di mana komputer yang digunakan mahasiswa untuk menjawab soal merupakan client dan komputer yang digunakan dosen untuk memantau serta mengisi soal merupakan server. Dalam menyelesaikan masalah yang timbul, suatu instansi harus memiliki sistem yang dapat mengatasi masalah tersebut. Sistem yang diusulkan dalam mengatasi permasalahan adalah sistem komputerisasi untuk menghasilkan informasi yang efektif dan efisien, serta membuat laporan yang lebih cepat dan akurat. Aplikasi simulasi ujian yang dirancang sangat membantu dosen untuk melaksanakan dan memeriksa hasil ujian dengan cepat dan tepat.
\end{abstract}

Kata Kunci : Client Server; arsitektur; dosen; mahasiswa.

\section{Pendahuluan}

Pada era saat ini, di mana teknologi telah menjadi suatu kebutuhan, tidak hanya dalam hal sumber informasi melainkan juga sebagai alat untuk mengolah data. Diiringi juga dengan fasilitas jaringan komputer yang memudahkan kita untuk terhubung, tidak hanya pada jaringan lokal namun juga terhubung keseluruh dunia melalui internet yang memungkinkan kita untuk berbagi data kapanpun dan di mana pun kita berada tanpa dibatasi ruang dan waktu (Aji et al., 2017)(Wongkar et al., 2015).

Dengan berkembangnya ilmu pengetahuan dan teknologi informasi yang sangat cepat dapat ditandai dengan perubahan perilaku salah satunya dalam hal pencarian informasi, ujian, dan lain - 
lain. Dampak yang luar biasa bagi lembagalembaga yang bergerak dalam bidang jasa informasi dan pendidikan (Musrifah, 2017)

Sistem adalah suatu kumpulan atau himpunan dari unsur, komponen atau variabel yang terorganisasi, saling berinteraksi, saling tergantung satu sama lain dan terpadu (Permana, 2017)

Dengan berkembangnya IPTEK yang luar biasa pesatnya, tidak menutup kemungkinan banyak instansi yang akan beralih ke fase tersebut. Salah satu nya pada bidang pendidikan pada perguruan tinggi. Banyak peneliti yang ada di perguruan tinggi berlomba melakukan terobosan atau inovasi-inovasi guna mempercepat proses kerja dari suatu sistem. Salah satunya yang sangat dibutuhkan adalah kebutuhan perangkat lunak, di mana kebutuhan yang semakin meningkat dan untuk mengefisienkan waktu akan proses pengintegrasian data, pendistribusian berbagai informasi menjadikan perangkat lunak dan sistem jaringan semakin diminati untuk diterapkan di suatu Institusi pendidikan. Terutama dalam hal proses ujian pada akhir semester, supaya memudahkan dari proses ujian dan dapat ditingkatkan dengan cara pengelolaan pembelajaran secara bersama (Windana et al., 2015)

Arsitektur dari jaringan client server merupakan sautu model konektivitas pada jaringan yang membedakan fungsi komputer sebagai terminal akses serta pusat pengolahan dan layanan. Arsitektur ini menempatkan sebuah komputer sebagai server. Yang bertugas memberikan pelayanan kepada terminal-terminal lainnya yang terhubung disebut dengan client. Arsitektur client server dibagi menjadi empat macam yaitu : client server one tier, client server two tier, client server three tier dan client server multi tier. Pada jaringan ini, server menyimpan berbagai data yang dapat diakses oleh pengguna melalui terminal-terminal client (Jasri, 2018)

\section{Landasan Teori}

Sistem jaringan komputer atau yang lebih dikenal dengan LAN (Local Area Network) adalah sistem yang menjadi solusi untuk menjalankan suatu Sistem Informasi Manajemen (SIM) disebuah instansi, baik itu bidang jasa maupun pendidikan tinggi. Dengan fungsinya LAN dapat menghubungkan beberapa computer yang terhubung, atau pada umumnya Personal Computer (PC), sehingga dapat mengakses ke komputer dan peripheral seperti perangkat keras pendukung yang terhubung dengan LAN tersebut.

Metode client server merupakan metode yang di mana antara server dan client saling terpisah. Server memberikan informasi maupun pelayanan kepada client, dan client menerima dari fasilitas layanan yang diberikan oleh server. Antara komputer Server dan komputer client dapat saling melakukan komunikasi dengan menggunakan sistem aplikasi jaringan yang disebut dengan server. Masing-masing client dapat meminta data atau informasi dari server. Sistem client server didefinisikan sebagai sistem terdistribusi (Sukrianto, 2019)

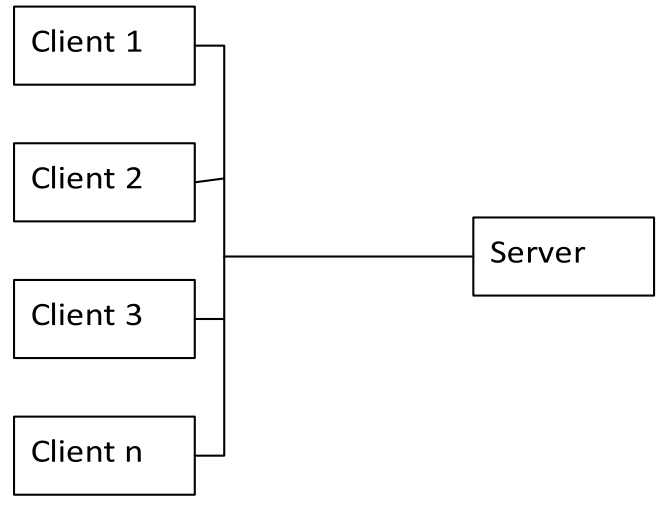

Gambar 1. Arsitektur Client Server

\section{Metode Pengumpulan Data}

Tahapan yang akan penulis lakukan dalam melakukan penelitian ini adalah:

a. Data Primer: yaitu tahapan yang penulis lakukan dengan cara observasi ke lapangan dan langsung mencari sumber dari objeknya yang meliputi data mahasiswa, data dosen, data mata kuliah serta data-data ujian.

b. Data Sekunder: yaitu tahapan di mana penulis mendapatkan data dari sumber lain dalam bentuk tulisan ilmiah atau publikasi, buku-buku dari perpustakaan dan sumber lain yang penulis ambil dari luar Institusi.

Berikut ini Data Flow Diagram yang akan penulis gunakan dalam merancang dari penelitian ini .

a. Diagram Konteks

Mahasiswa, dosen dan pimpinan telah terhubung dengan server. Status mahasiswa sebagai peserta dan mengikuti ujian yang diberikan oleh dosen. Dari hasil aktifitas simulasi tersebut, baik dosen maupun pimpinan 
dapat mengetahui nilai dari hasil ujian yang dilakukan mahasiswa tersebut.

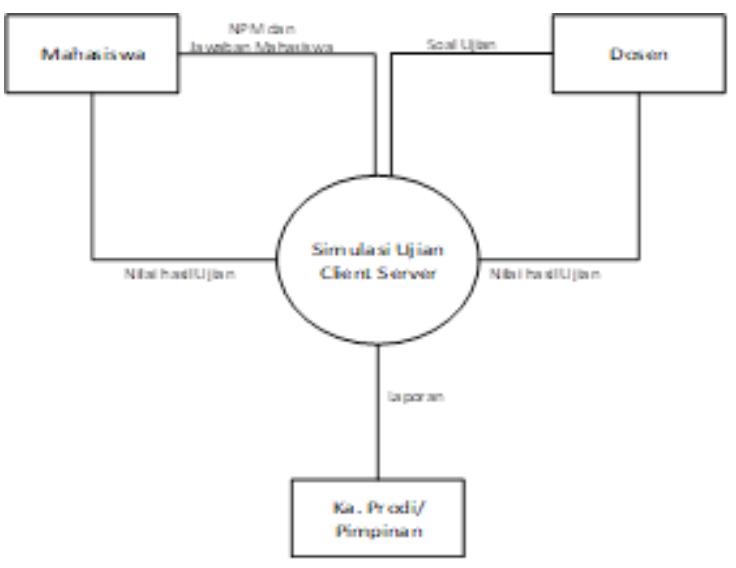

Gambar 2. Diagram Konteks

b. Data Flow Diagram (DFD)

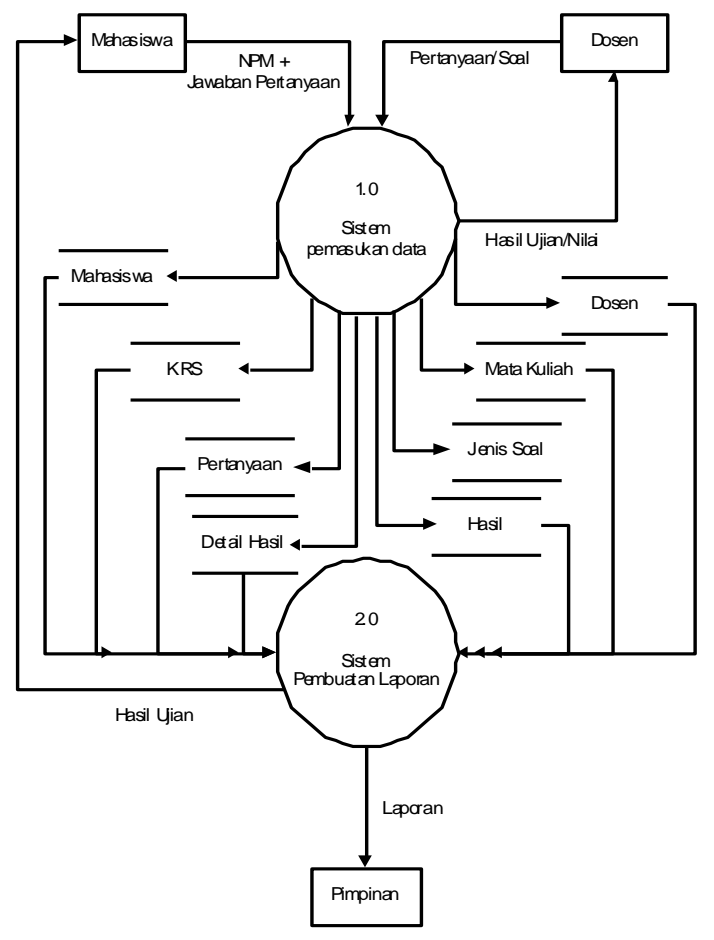

Gambar 3. Data Flow Diagram (DFD)

\section{Analisis dan Implementasi}

Setelah data diperoleh, sehubungan dengan masalah yang dihadapi maka metode analisis dari masalah ini adalah:

a. Metode Deskriptif

Yaitu dalam hal ini penulis mengumpulkan data, mengelompokkan dan menganalisa data yang berkenaan dengan data mahasiswa, data dosen, kurikulum mata kuliah, dan format pelaporan nilai, sehingga memberikan gambaran atau keterangan yang lengkap dan jelas tentang masalah.

b. Metode Deduktif

Yaitu metode yang penulis gunakan dalam merumuskan suatu kesimpulan yang logis dan dapat diterima umum baik mengenai persesuaian dari penelitian atau antara keduanya maupun penyimpangan yang ada.

\section{Hasil dan Pembahasan}

Hasil dari penelitian yang penulis lakukan dapat digambarkan berupa flowchart dan tampilan screenshot dari program yang penulis rancang. Tampilan rancangan yang penulis lakukan dimulai dari halaman depan sistem, dapat dilihat pada gambar 4 .

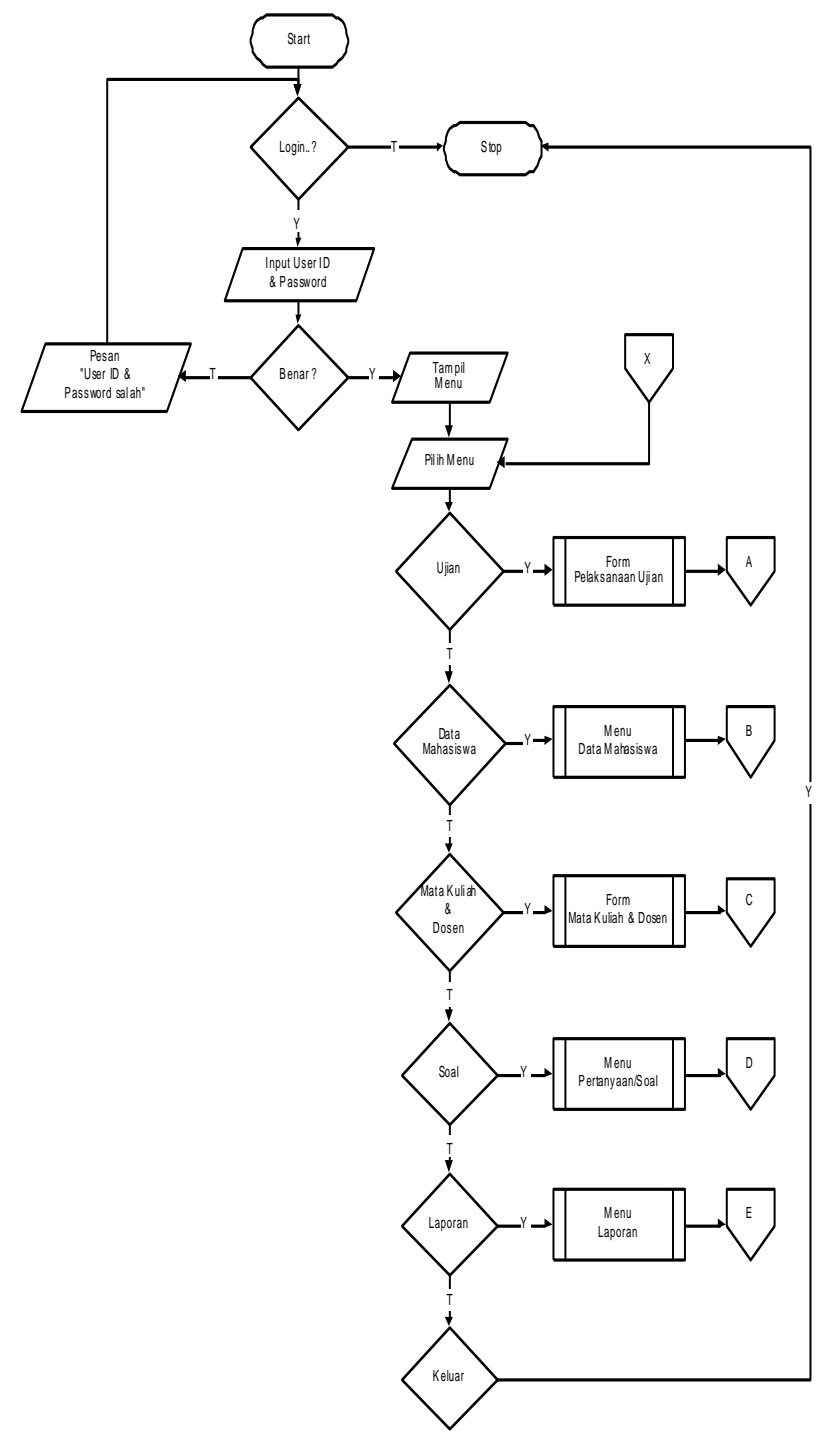

Gambar 4. Flowchart tampilan aplikasi 
Flowchart di atas merupakan tampilan utama dari sistem aplikasi yang akan penulis rancang. Tampilan tersebut yang akan tampil di jendela komputer masing - masing mahasiswa dan tampil di server. Tampilan dari sistem ini terdiri dari beberapa menu, yaitu: Menu Ujian, Data Mahasiswa, Mata Kuliah dan Dosen, Soal, Laporan.

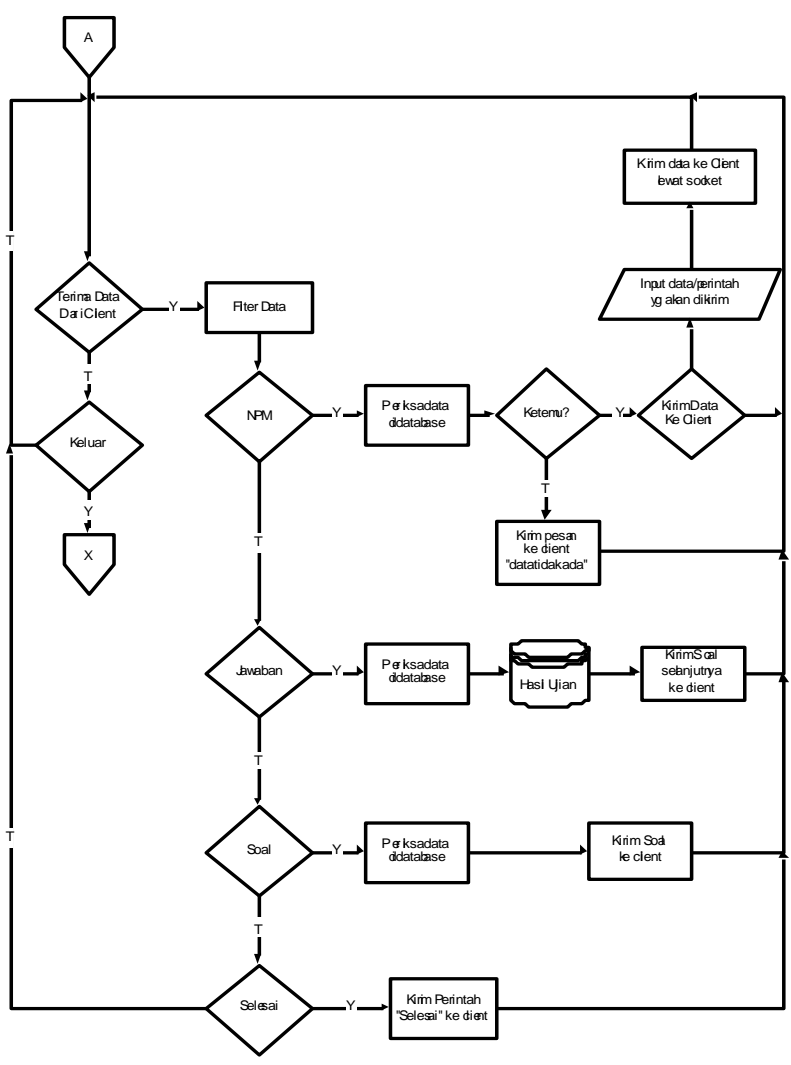

Gamber 5. Flowchart Server Ujian

Gambar di atas menjelaskan bahwa soal yang diberikan dosen dimasukkan ke dalam server yang telah terhubung dengan PC Client. Mahasiswa dapat mengakses soal dan memberikan jawaban dari soal yang diberikan dosen melalui PC Client masing- masing.

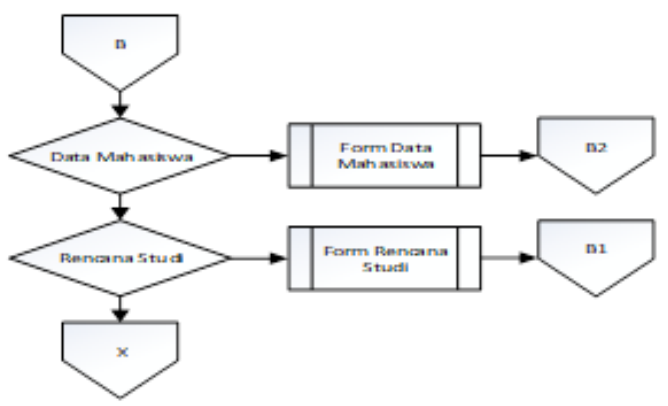

Gambar 6. Flowchart Menu Data Mahasiswa

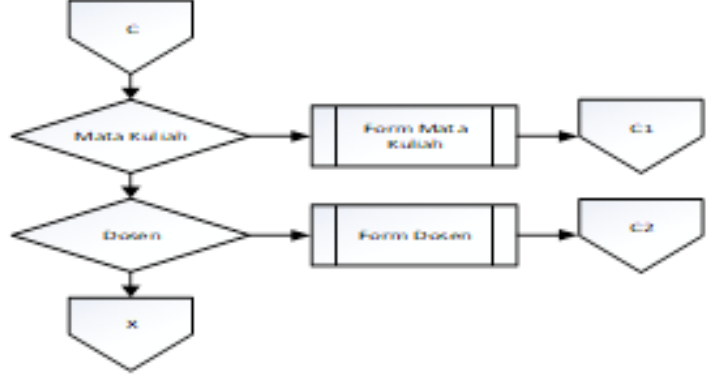

Gambar 7. Menu Dosen dan Mata Kuliah

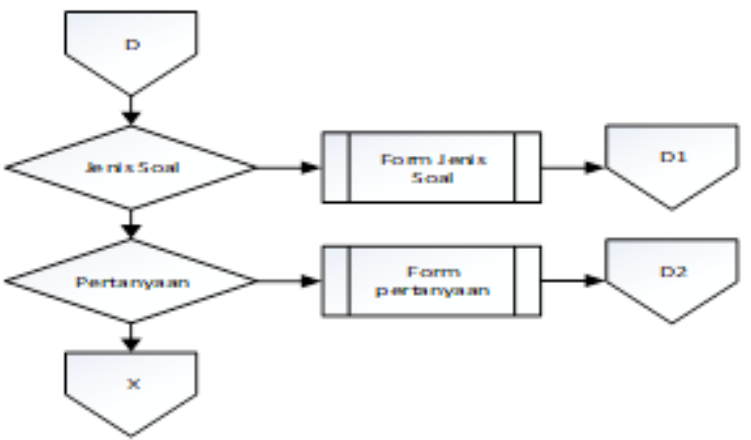

Gambar 8. Menu Soal/Pertanyaan

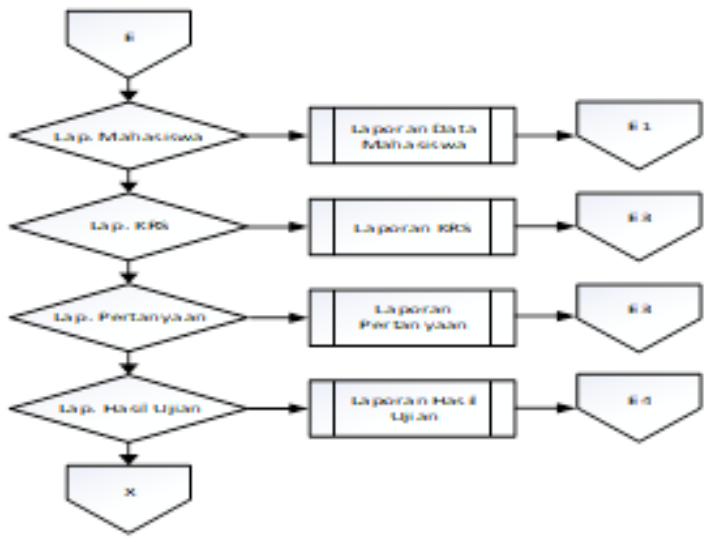

Gambar 9. Flowchart Menu Laporan 


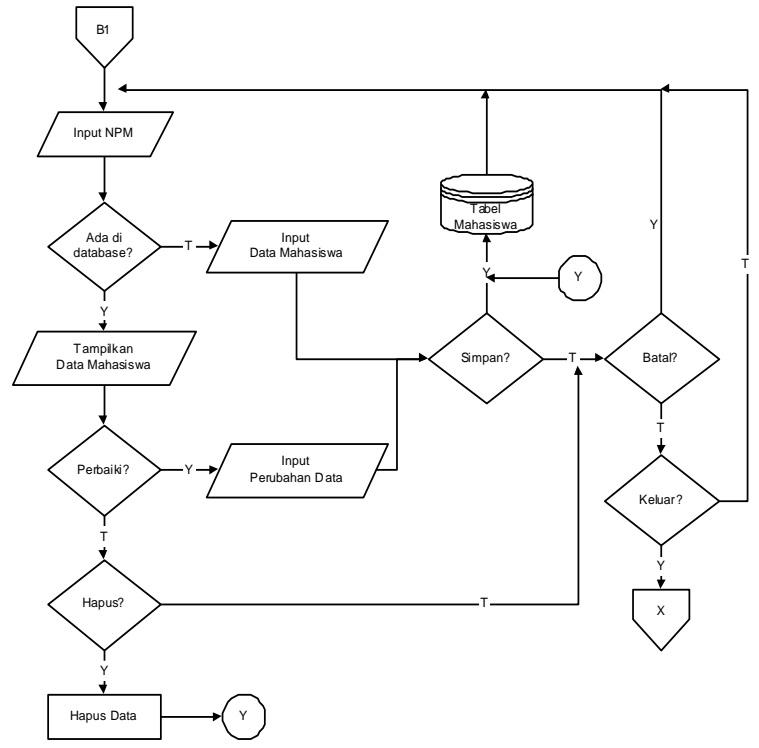

Gambar 10. Flowchart Data Mahasiswa

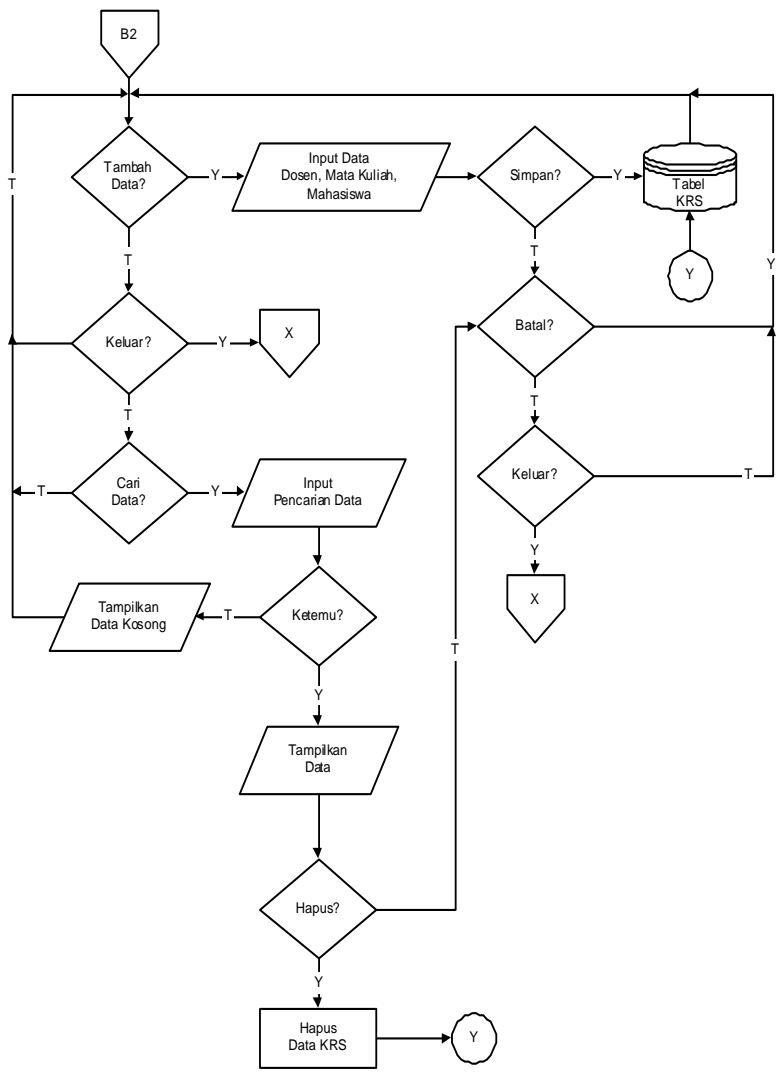

Gambar 11. Flowchart Data KRS

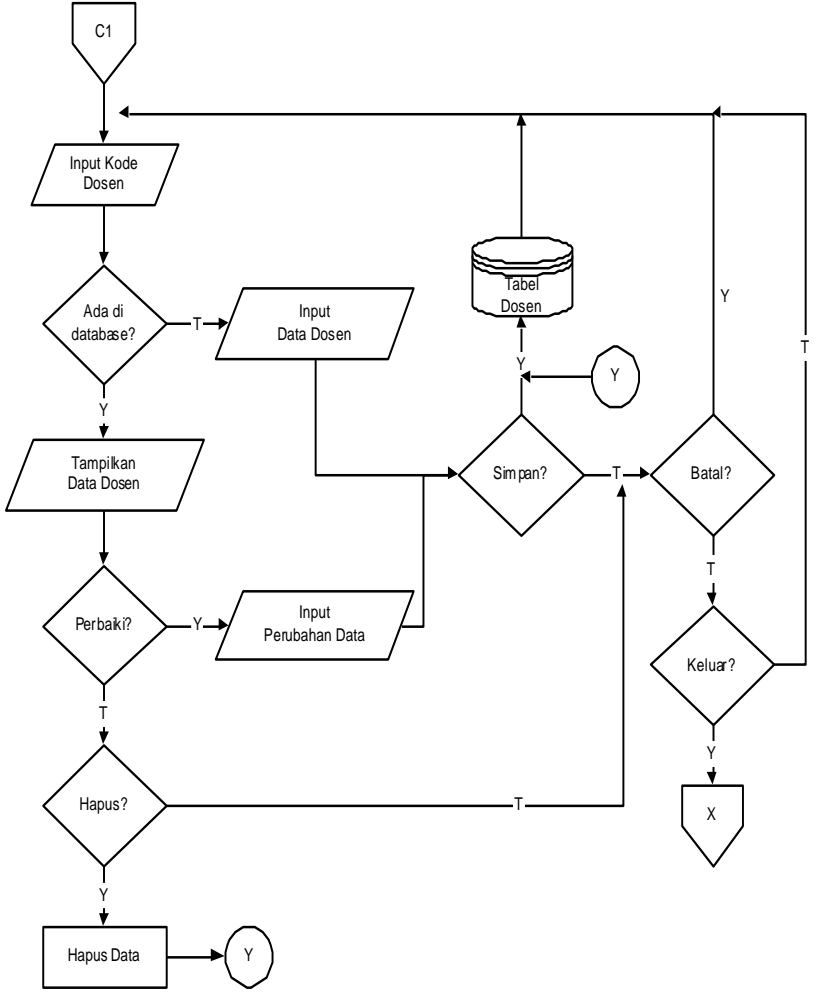

Gambar 12. Flowchart Data Dosen

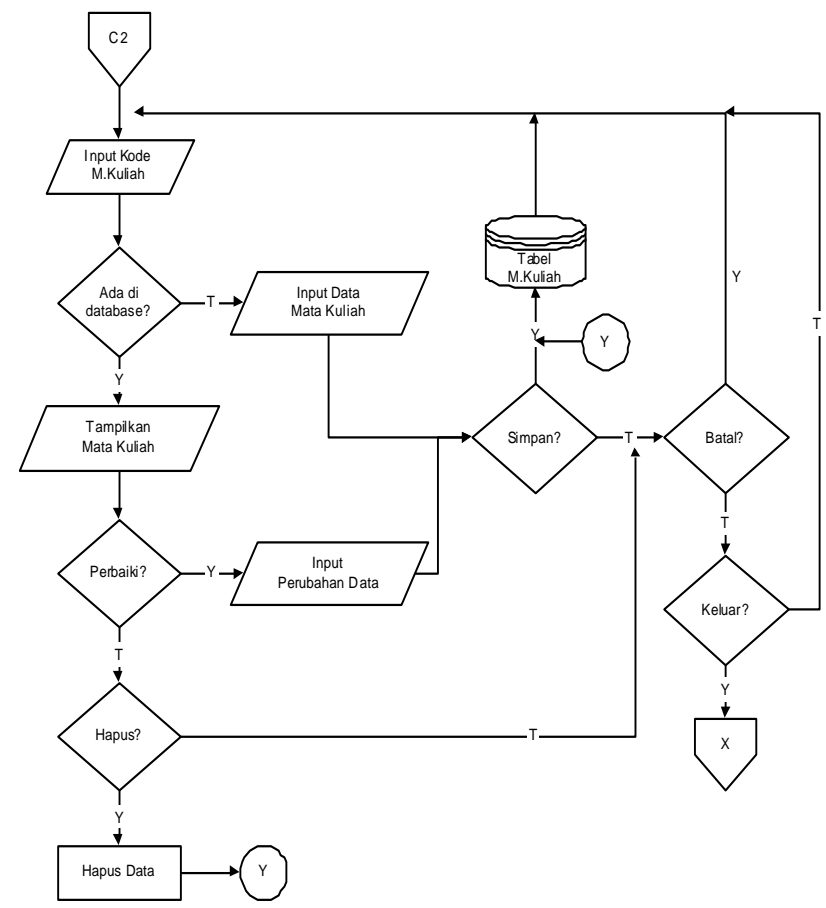

Gambar 13. Flowchart Mata Kuliah 


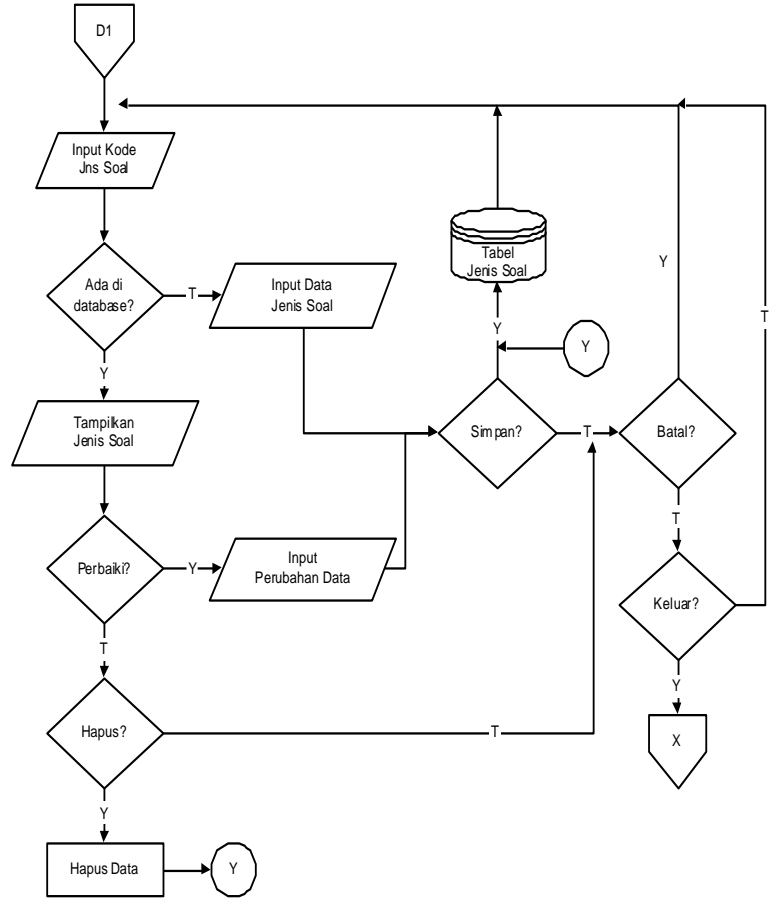

Gambar 14. Flowchart Jenis Soal

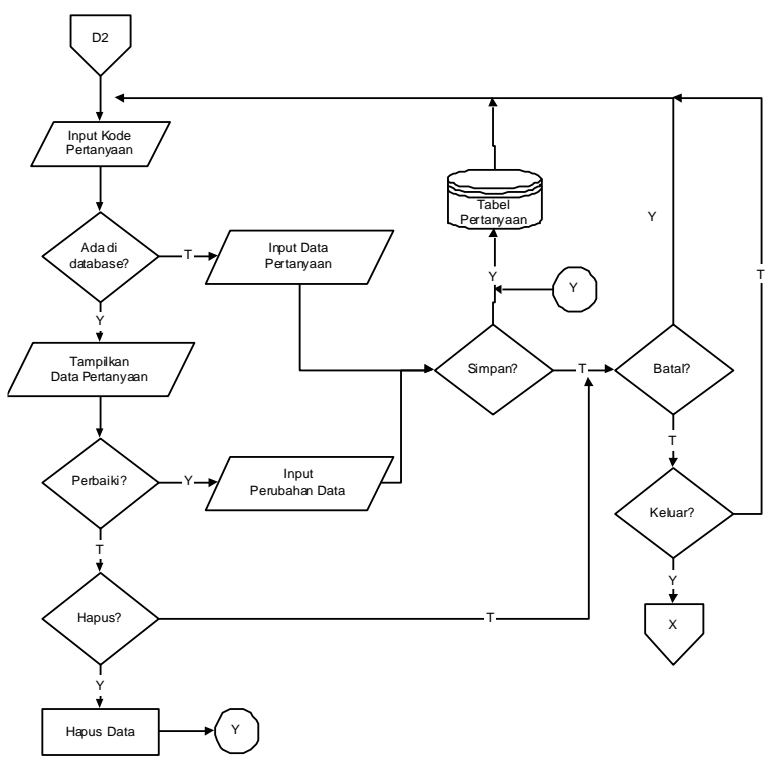

Gambar 15. Flowchat Pertanyaan

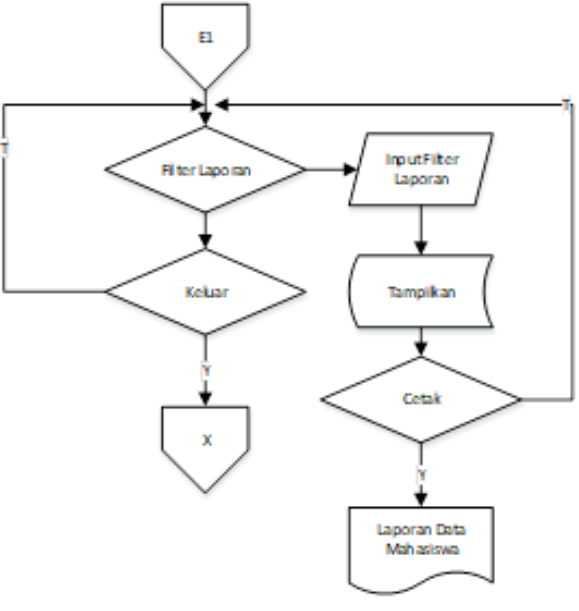

Gambar 16. Laporan Data Mahasiswa

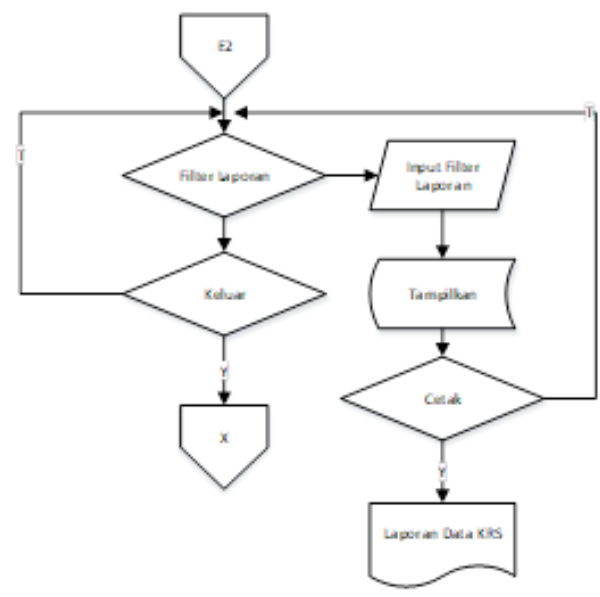

Gambar 17. Laporan Data KRS

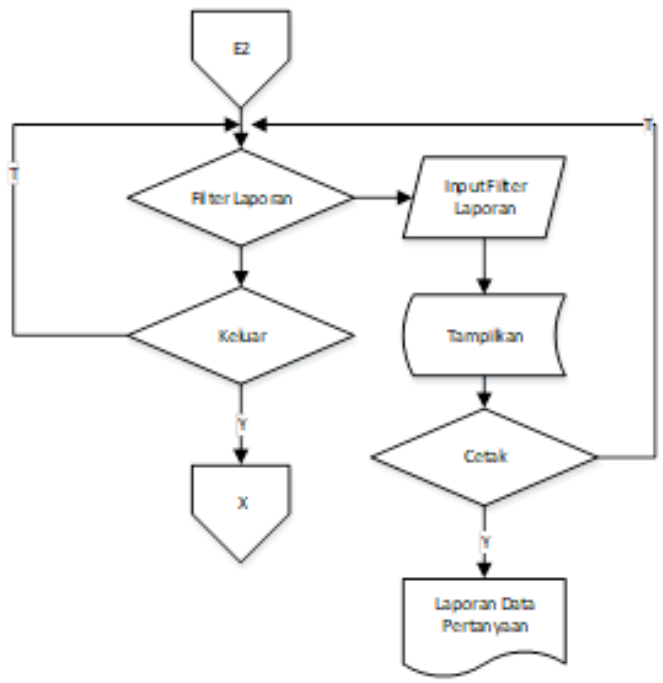

Gambar 18. Laporan Data Pertanyaan 


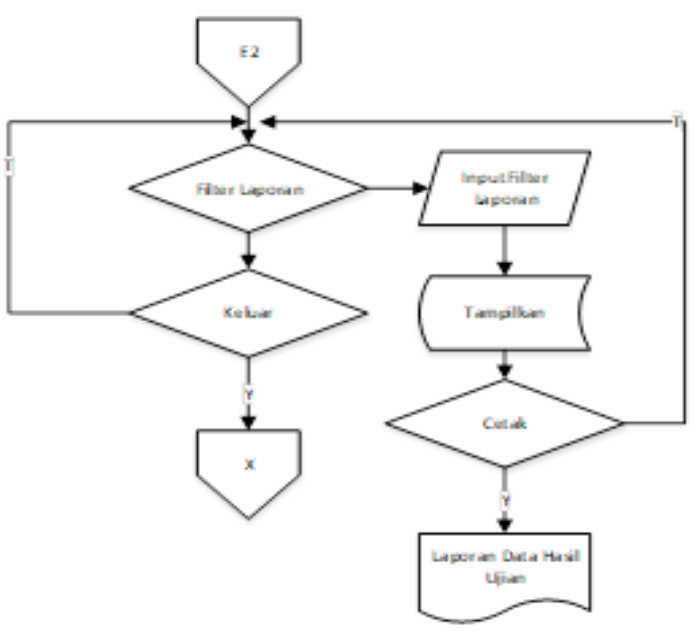

Gambar 18. Laporan Data Hasil Ujian

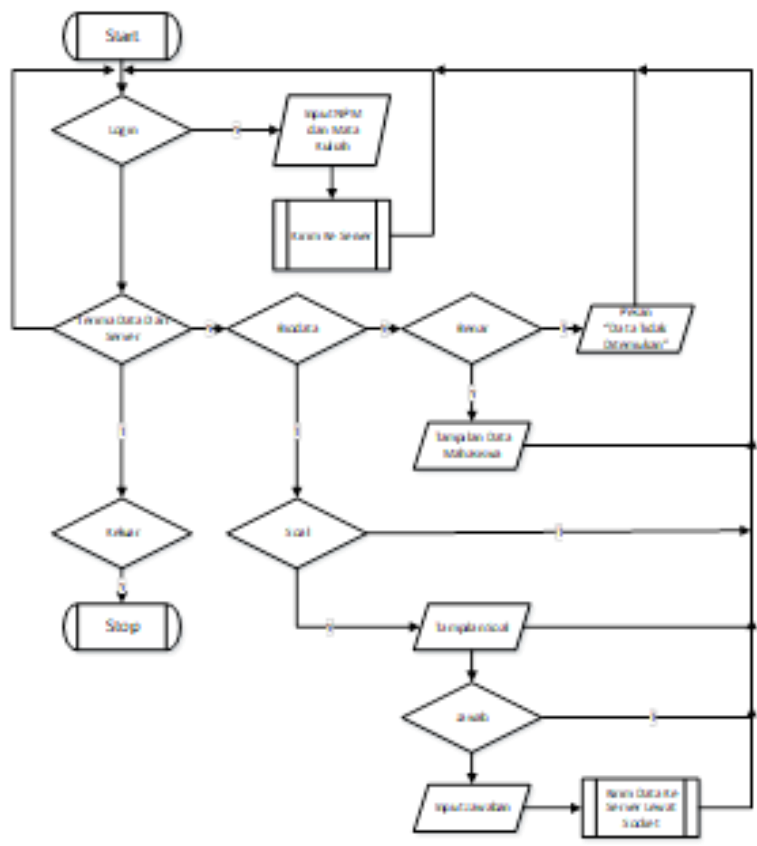

Gambar 19. Flowchart Client

\section{Tampilan Layar, Tampilan Form Masukan Data dan Tampilan Keluaran}

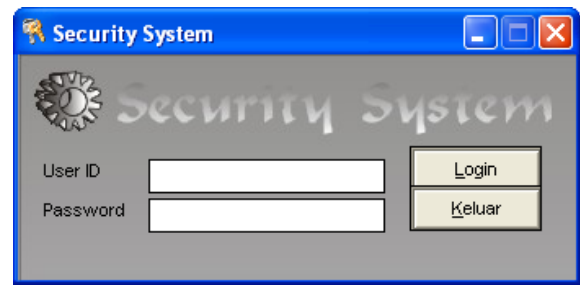

Gambar 20. Tampilan log in administor
Log in administrator digunakan sebagai akses masuk mahasiswa maupun dosen ke dalam perangkat lunak simulasi ujian. Akses untuk log in ini jika sebagai dosen menggunakan NIDN sebagai user ID dan Password, sedangkan untuk mahasiswa menggunakan Nomor Induk Mahasiswa.

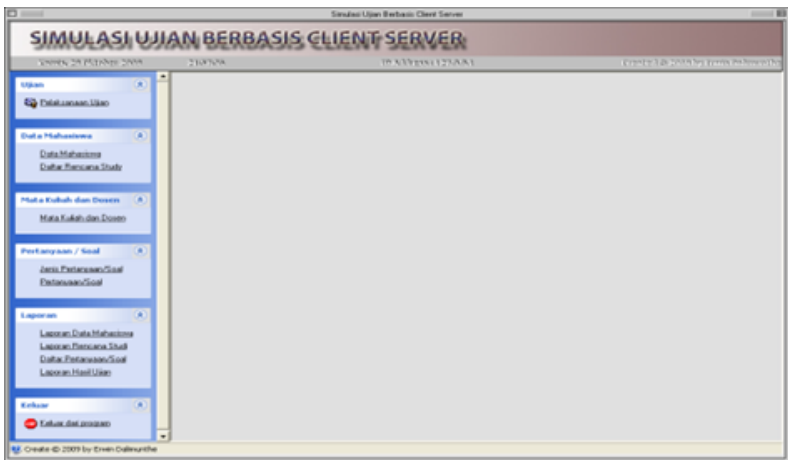

Gambar 21. Menu Utama

Menu utama merupakan tampilan dari sistem aplikasi ini. Pada menu utama inilah baik Dosen maupun mahasiswa dapat memilih menu yang akan diakses. Mahasiswa harus memahami intruksi yang diberikan oleh dosen untuk mengakses menu sesuai dengan kegiatan yang akan dilaksanakan.

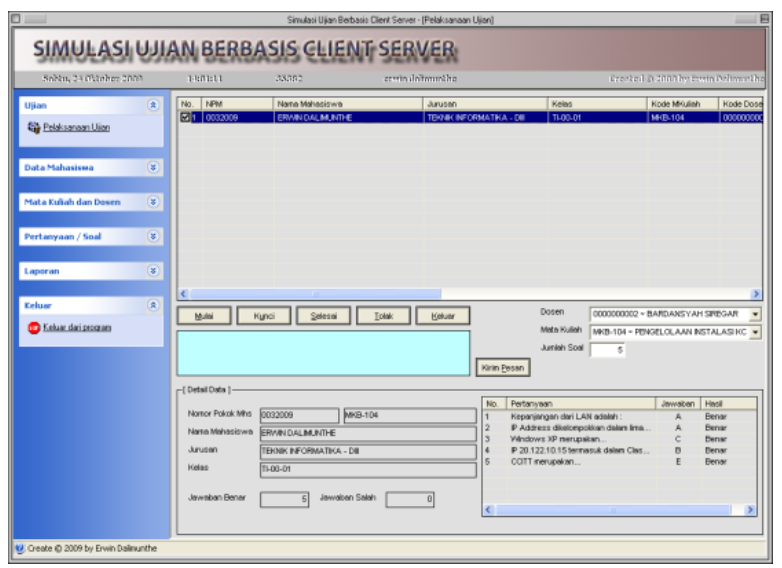

Gambar 22. Tampilan pelaksanaan ujian

Gambar di atas menjelaskan tentang menu pelaksanaan ujian. Pada pilihan menu ini untuk hal ini hanya bisa diakses oleh dosen pada komputer server dengan tujuan untuk memantau aktifitas ujian dari yang sedang dijalankan oleh mahasiswa. 


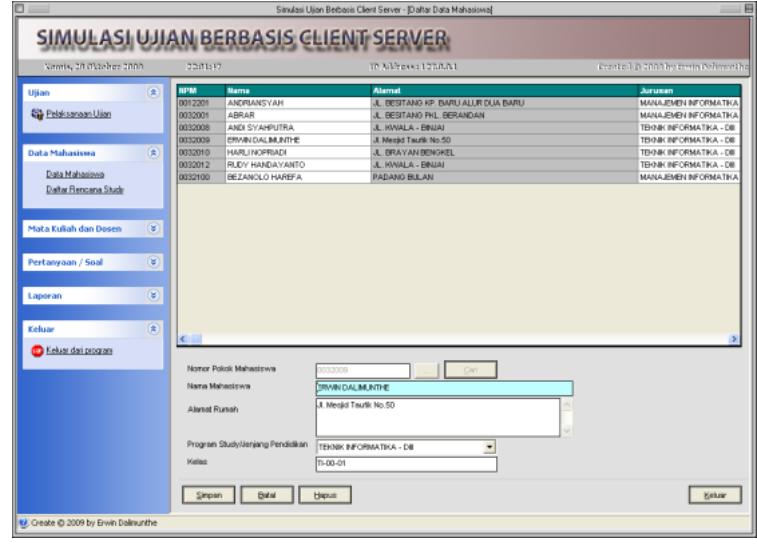

Gambar 23. Tampilan data mahasiswa

Pada pilihan Menu data mahasiswa, dosen dapat mengetahui nama-nama mahasiswa yang sedang mengikuti proses ujian. Menu ini hanya dosen yang dapat mengakses dari komputer server.

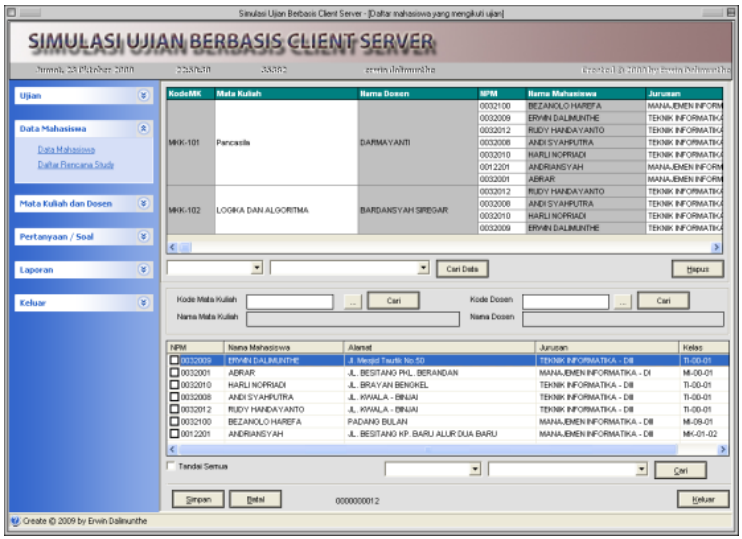

Gambar 24. Tampilan menu daftar rencana studi

Tampilan pada menu Daftar rencana studi, merupakan dari tampilan menu mata kuliah yang telah diambil oleh mahasiswa. Pada menu ini, baik dosen maupun mahasiswa diberi hak untuk mengaksesnya. Dengan tujuan memudahkan si dosen untuk mengetahui nama-nama dari mahasiswa yang berhak mengikuti jadwal untuk melaksanakan ujian.

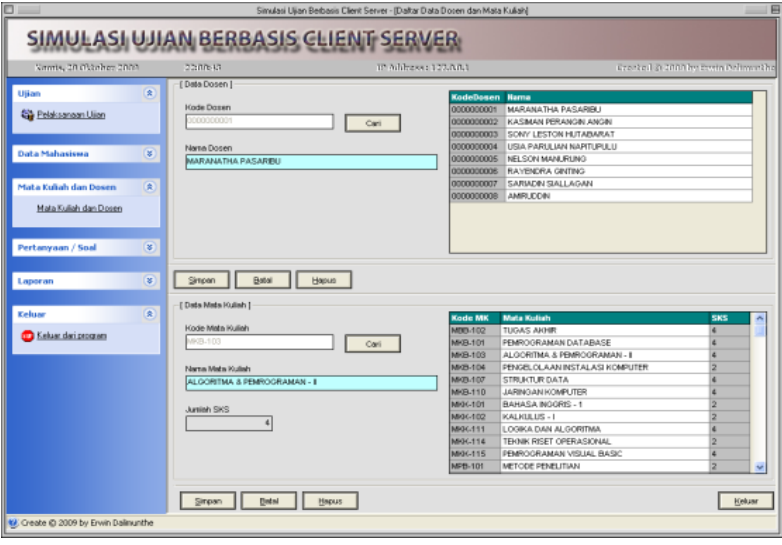

Gambar 25. Tampilan mata kuliah dan dosen

Tampilan pada menu Mata Kuliah dan Dosen merupakan tampilan yang penulis buat untuk memudahkan mahasiswa memilih mata kuliah yang akan melaksanakan ujian. Pada menu ini baik dosen dan mahasiswa mempunyai akses tersebut.

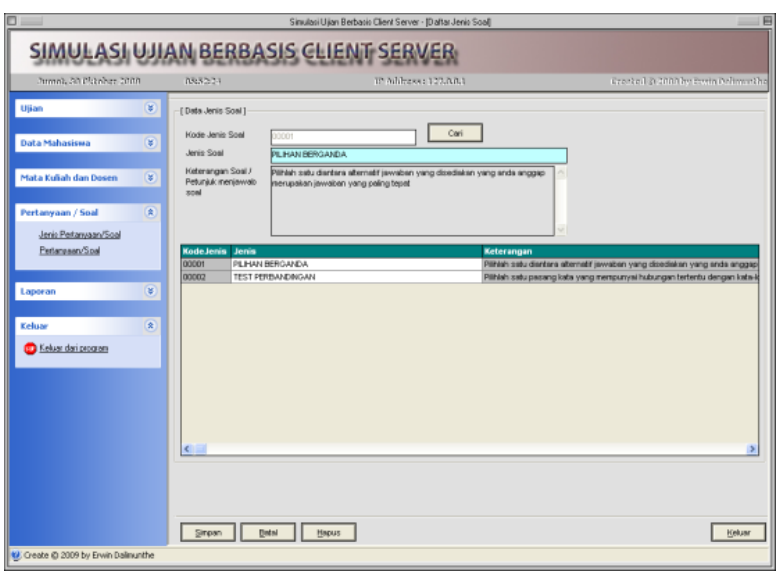

Gambar 26. Tampilan jenis pertanyaan/soal

Tampilan pada menu pertanyaan/soal merupakan pilihan jenis soal yang akan mahasiswa pilih. Akan tetapi dalam hal ini penulis mengintruksikan kepada dosen untuk membuat soal dengan jenis choice. Tetapi ada juga pada beberapa mata kuliah yang memberikan jenis soal berupa studi kasus maupun essay. 


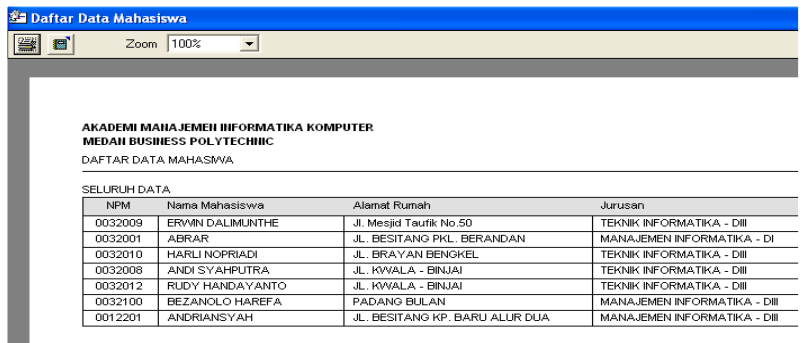

Gambar 27. Tampilan laporan data mahasiswa

Tampilan dari laporan data mahasiswa tersebut merupakan tampilan dari data mahasiswa yang mengikuti simulasi pada ujian yang sedang dilaksanakan. Tampilan ini penulis buat sebagai bahan untuk laporan aktifitas dosen kepada pimpinan.

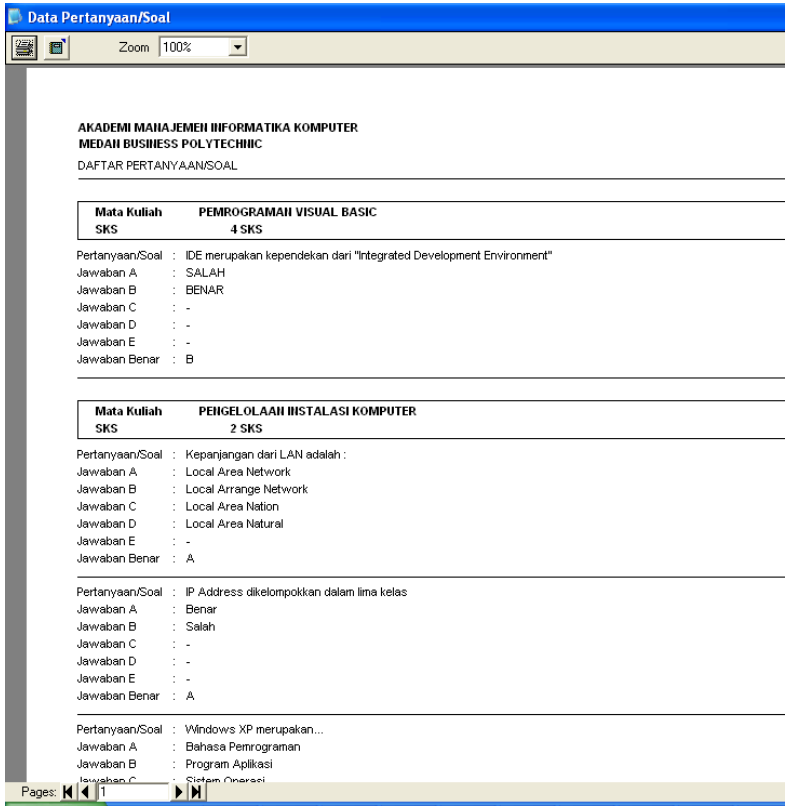

Gambar 28. Tampilan laporan soal

Tampilan pada menu laporan soal merupakan tampilan yang digunakan sebagai bahan laporan ke pimpinan. Pimpinan juga harus mengetahui jenis soal yang dibuat oleh dosen apakah sesuai dengan kurikulum yang telah berikan kepada mahasiswa. Selain itu laporan soal akan dijadikan sebagai file oleh bidang akademik dalam proses pengumpulan soal ke dalam bank soal.

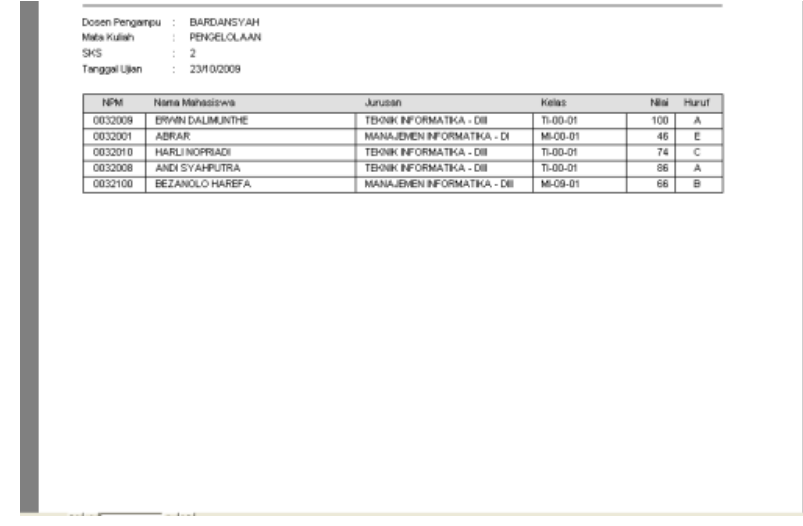

Gambar 29. Tampilan Laporan hasil ujian

Tampilan dari menu laporan hasil ujian merupakan hasil akhir yang mahasiswa peroleh dari aktifitas mahasiswa peserta simulasi ujian yang telah dibuat. Laporan hasil ujian atau Kartu Hasil Ujian ini merupakan laporan final seorang dosen kepada pimpinan bahwa proses belajar mengajar pada periode semester telah berakhir.

\section{Kesimpulan}

Berdasarkan hasil analisis penulis selama melakukan aktifitas dengan merangcang aplikasi simulasi ujian, penulis mengambil kesimpulan bahwa:

1. Aplikasi simulasi ujian yang penulis rancang sangat membantu dosen untuk melaksanakan dan memeriksa hasil ujian dengan cepat dan tepat.

2. Aplikasi simulasi ujian yang penulis buat dirancang untuk jaringan lokal (Local Area Network/LAN).

\section{Referensi}

Aji, S., Fadlil, A., \& Riadi, I. (2017). Pengembangan Sistem Pengaman Jaringan Komputer Berdasarkan Analisis Forensik Jaringan. Jurnal Ilmiah Teknik Elektro Komputer Dan Informatika, $3(1), \quad 11$. https://doi.org/10.26555/jiteki.v3i1.5665

Jasri, J. (2018). Arsitektur Three Tier (Client Server Programing) Pada Aplikasi Perpustakaan Fakultas Teknik Universitas Muhammadiyah Bengkulu. Journal of Technopreneurship and Information System (JTIS), 1(1), 19-25. https://doi.org/10.36085/jtis.v1i1.56

Musrifah. (2017). Implementasi Teknologi Informasi Menggunakan Human Organization Technology (HOT) Fit Model di Perpustakaan Perguruan Tinggi. Jurnal Ilmu Perpustakaan Dan Informasi (JIPI), 2(2), 222-242.

Permana, A. A. (2017). Rancangan Sistem Informasi Simpan Pinjam Pada Koperasi Guru Dan 
Pegawai Smp Negeri 45 Jakarta. JIKA (Jurnal Informatika), 1(2), 51-58. https://doi.org/10.31000/jika.v1i2.1400

Sukrianto, D. (2019). Perancangan Sistem Informasi Berbasis Client Server Pada Sma Negeri 7 Menggunakan Bahasa Pemrograman Berorientasi Objek. Journal of Chemical Information and Modeling, 53(9), 1689-1699. https://doi.org/10.1017/CBO9781107415324.004

Windana, F., Soepriyanto, Y., \& Praherdhiono, H. (2015). Pengembangan Perangkat Lunak Untuk Model Pengelolaan Kuliah Bersama pada Karakteristik Lembaga Penyelenggara Berbeda. Jurnal STT STIKMA Internasional, 6(1), 1-8.

Wongkar, S., Sinsuw, A., Najoan, X., Studi, P., Informatika, T., Teknik, F., \& Ratulangi, U. S. (2015). Analisa Implementasi Jaringan Internet Dengan Menggabungkan Jaringan Lan Dan Wlan di Desa Kawangkoan Bawah Wilayah Amurang Ii. E-Journal Teknik Elektro Dan Komputer, 4(6), 62-68.

https://doi.org/10.35793/jtek.4.6.2015.10400 